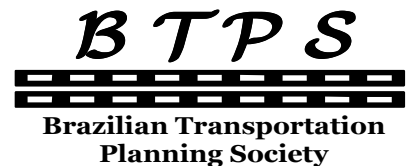

Planning Society
Journal of Transport Literature

Vol. 8, n. 1, pp. 8-23, Jan. 2014

Research Directory
JTL | RELIT

www.transport-literature.org ISSN 2238-1031

\title{
The main cost-related factors in airlines management
}

[Os principais fatores relacionados à gestão de custos em companhias aéreas]

\author{
Rogéria de Arantes Gomes Eller*, Michelle Moreira \\ Technological Institute of Aeronautics - Brazil
}

Submitted 12 Sep 2012; received in revised form 27 Jan 2013; accepted 28 Jan 2013

\begin{abstract}
This paper analyzes the main factors that affect the strategies to reduce airlines costs. These costs factors were presented to experts from the airline industry through two rounds of questionnaires in sense to be weighed. It was applied a method based on the structure of the AHP (Analytic Hierarchy Process) and the results show that the main important factors for a cost-related airlines strategy are, in importance: route structure and mesh; type and characteristics of the aircraft; cost of labor and management quality. This hierarchy can help the decision maker when facing the need of defining priorities in reduction costs. past decades despite the increase in air transportation and significant decrease in average operation costs, it is observed that airlines have low profitability. The liberalization of the markets and increase opportunities for competition diminishes prices, even when airlines face increasing costs. Considering that advantage in costs is an important strategy for carriers to remain in the market, this paper analyzes the main factors that affect the strategies to reduce airlines costs. These costs factors were presented to experts from the airline industry through two rounds of questionnaires in sense to be weighed. It was applied a method based on the structure of the AHP (Analytic Hierarchy Process) and the results show that the main important factors for a cost-related airlines strategy are, in order of importance: route structure and mesh; type and characteristics of the aircraft; cost of labor and management quality. This hierarchy can help the decision maker when facing the need of defining priorities in reduction costs.
\end{abstract}

Key words: air transportation, strategies, costs, AHP.

\section{Resumo}

Este trabalho analisa os principais fatores que afetam as estratégias de redução de custos das companhias aéreas. Esses fatores foram apresentados a especialistas do setor aéreo por meio de duas rodadas de questionários no sentido de serem ponderados. Aplicou-se um método baseado na estrutura do AHP (Analytic Hierarchy Process) e os resultados mostram que os principais factores importantes para uma estratégia de companhias aéreas relacionadas com os custos são, em ordem de de importância: estrutura de rotas e mesh, tipo e características da aeronave; o custo do trabalho e a gestão da qualidade. Esta hierarquia pode ajudar o tomador de decisão diante da necessidade de definição de prioridades na redução de custos. Nas últimas décadas, apesar do aumento do transporte de ar e redução significativa dos custos de funcionamento média, observa-se que as linhas aéreas têm baixa rentabilidade. A liberalização dos mercados e oportunidades de aumento de concorrência diminui os preços, mesmo quando as companhias aéreas enfrentam custos crescentes. Considerando que a vantagem de custos é uma estratégia importante para as transportadoras para permanecer no mercado, este trabalho analisa os principais fatores que afetam as estratégias de redução de custos das companhias aéreas. Esses fatores custos foram apresentados a especialistas do setor aéreo por meio de duas rodadas de questionários no sentido de ser ponderado. Aplicou-se um método baseado na estrutura da AHP (Analytic Hierarchy Process) e os resultados mostram que os principais factores importantes para uma estratégia de companhias aéreas relacionadas com os custos são, em ordem de importância: estrutura de rotas e mesh, tipo e características da aeronave; mão-de-obra e gestão da qualidade. Esta hierarquia pode ajudar o tomador de decisão diante da necessidade de definição de prioridades na redução de custos.

Palavras-Chave: transporte aéreo, estratégias, costs, AHP.

*Email: rogeria@ita.br.

\section{Recommended Citation}

Eller, R.A.G. and Moreira, M. (2014) The main cost-related factors in airlines management. Journal of Transport Literature, vol. 8, n. 1, pp. 8-23.

- JTL/RELIT is a fully electronic, peer-reviewed, open access, international journal focused on emerging transport markets and published by BPTS - Brazilian Transport Planning Society. Website www.transport-literature.org. ISSN 2238-1031. 


\section{Introduction}

Over the past 50 years, civil aviation has grown dramatically. The rate of technological change has been outstanding resulting in a decrease in costs and prices, which stimulated a rapidly growing demand for their services (Doganis, 2010).

However, Doganis (2010) highlights a paradox. Most industries and businesses that have a continuous and rapid growth in demand for their products or services have a substantial increase in their profits. It does not happen with the airlines. These usually have a low profit, in general.

The deregulation process of markets and increasing opportunities for competition have created excess capacity in many markets that causes lower rates, even with its rising costs. The strategic costs management as well as their behavior under different influences can bring competitive advantage over players.

Cost reduction in the market-based industry is a very important way of being competitive when facing prices decreasing. So, reduce total cost is relevant but the influence of each component on total cost depends on factors that are related or not to airline operation.

Air transportation industry is characterized by being dynamic, with rapid changes in many of its features. For this reason, the clear knowledge of the costs involved and its determinants is essential for decision making of business (Doganis, 2010).

Considering the Brazilian civil aviation market, growth in recent years has been higher than the country's economy. Between 2000 and 2008, Brazilian commercial aviation had an increase in the supply of available seat kilometers (ASK) in the domestic market about 57\% (ANAC, 2008). For the same period, the Gross Domestic Product (GDP) grew 7.5\% (Ministry of Finance, 2011). It is important to point out that the air transportation rate can be assumed as an exceptional case.

In this scenario, new companies emerged in the market and others stopped operating. Some of them adopt the low-cost model, like GOL, which began its operations in 2001. The lower rates stimulated a growing demand for air transport, which compete for passengers with 
traditional modes as road transport. The more markets are competitive the more is important to be efficient. In this context, strategies to reduce operating costs are becoming very important.

The decision about the relevance of one cost is not a simple matter. The effectiveness of reduction of each item that composes the total cost of airline can change over time, depending on both the business model and the stage of the company, as well as external factors.

In this scenario this research aims to determine the main factors that influence the strategies of reducing airline's costs. Furthermore, the proposal is to establish a hierarchy of these factors according to their importance. It could be relevant for helping the manager when facing decisions about measures of costs reduction and efficiency focusing their efforts and set priority actions. To reach this objective it was applied a structure based on the method of decision support AHP (Analytic Hierarchy Process), in which the weights of the factors were determined through questionnaires sent to experts in the field.

This paper is presented in six parts: Section 1 is related to strategy and costs and aims to show the implication of cost reduction and airline's strategy; Section 2 discusses the most important airlines costs and its characteristics; Section 3 shows different types of airlines business; Section 4 presents the methodology used to develop this study. Finally, Section 5 shows the results and Section 6 brings the conclusion of the paper.

\section{Strategy and costs}

Several factors such as technological development, market integration and competition have increased the changes in air transportation. According to Borenstein and Rose (2007) government policy rather than market forces shaped the development and operation of scheduled passenger air service in almost all markets. In Brazil it was specially verified during the 90's.

Wei and Hansen (2003) say that deregulation is a fait accompli and nowadays the challenge refers to accommodate rising traffic in an infrastructure that is technically and politically difficult to expand. But they also consider that the airlines concerns have importance to regulatory policy so this paper discussion is developed at the firm level. 
In this free market environment it is required from decision makers to develop strategies that will ensure competitive advantages in order to reach their goals in both short and long term. It should be pointed out that average price is explained by variables that reflect cost besides demand and market structure conditions (Barla and Koo, 1999).

According to Carrilho (2009), strategy is a set of goals and plans and resources to achieve these goals. Thus, the definition of the objectives does not characterize a strategy. These represent the purposes that the company decided to reach, and the strategy means how to get these objectives. To create their strategies, companies are based on three main topics: their external environment, internal environment and the ability to add value to the service they provide.

Coelho (2010) shows there are three types of competitive advantage: differentiation, cost and agility. The differentiation may be related to a product of superior quality, high value of the brand or the company's positive reputation. The cost advantage is related to techniques that reduce production costs, making it possible to offer cheaper products than the competition. Agility refers to the speed which the company responds to market demands. This paper addresses strategies that seek competitive advantage in costs for the airlines.

\section{Airlines' costs}

The revenue and cost structure of an airline is traditionally divided between operating and non-operating issues.

For some companies, non-operating factors have major impact on their financial performance. An example is the Singapure Airlines (SIA), which in 2006 produced net undiscounted taxes US\$ 1,456 million and less than a half (49.2\%) were derived from operational factors (Doganis, 2010).

On the operating side costs can be divided into direct and indirect. In direct costs, one should include all costs that depend on the type of aircraft, for example, costs of flight (crew and fuel), all maintenance and overhaul of aircraft and depreciation costs. In the indirect costs are included all the costs that remain unchanged with the change of plane, i.e., costs that are not directly dependent on aircraft operations. 
Costs are derivatives which mean they are caused by others factors. The factors that cause costs are called determinants of costs. For a long time, the volume of production was considered as the sole determinant of cost, given that the larger the market share (higher volume production), the lower the average unit cost. Porter (1992), however, pointed out that there are others important factors to be considered, like economies of scale using the standard capacity, location and learning.

Brazilian National Agency of Civil Aviation (ANAC) shows that fixed costs represent approximately $65 \%$ of airline's total costs (BRASIL, 2005). In this markets for which fixed costs are high changes in production volume do not modify significantly the overall cost of the company. Thus, it is necessary to know better other determinants of costs.

Doganis (2010) defines a division for the determinants of costs for airlines according to degrees of management and control that are showed in Table 1.

Table 1 - Factors affecting the costs of airlines ${ }^{1}$

\begin{tabular}{|l|l|}
\hline \multicolumn{1}{|c|}{ Cost determinant } & Degree of management/control \\
\hline Externally determined input costs & Little \\
\hline Cost of labor & Some \\
\hline Type/characteristics of the aircraft & Some \\
\hline Route structure/network characteristics & Some \\
\hline Airline marketing and product policy & High \\
\hline Airline financial policy & High \\
\hline Corporate strategy & High \\
\hline Quality of management & High \\
\hline
\end{tabular}

In the first category are external factors over which companies have little control. The most relevant factor in this category is the price of fuel, but it can also mentioned airport taxes and fees over flight.

\footnotetext{
${ }^{1}$ Source: Doganis (2010).
} 
The determinants of cost on which the airline has some control are in the second category. Here, the three main determinants are the cost of labor, the type of aircraft used and the standard operations for which the aircraft is used. Although the latter two determinants appear to be under total control of the company, in practice, the action of managers is limited. It can be related to geographical location of the company, bilateral air service agreements made between governments and the density of traffic on its routes, which strongly influence the type of aircraft required and the network to be operated. The only case in which the management has more freedom to act is the national companies in countries with a single flag carrier, especially if it is majority owned by the government.

The last category of costs determinants is the one in which the manager has high or total control. Some items that can be part of this category are marketing, product planning, financial policies and business strategy. In addition, the quality of management and its efficiency can be considered determinants of cost, since they determine the degree of impact of other factors mentioned above.

All these categories can be applied to one airline with no dependence of the business model but it is considered that there are differences in the degrees of management and control.

\section{Types of airlines}

The airlines can be divided according to business models: intercontinental, national or regional, low-cost airlines or charter companies. In general, companies intercontinental, national or regional follow a traditional model, characterized by the presence of hubs and a large number of destinations. Charter companies usually have flights to some destinations in certain seasonality, with no-regular flights (Carrilho, 2009). In general airlines can be classified into two categories: low-cost and full service. The low-cost model is treated in the next topic.

\subsection{Low-cost model}

According to Doganis (2010), low costs carriers are based on two ideas. The first one is to be simple; offering a simple product or service based on simple operations and thus minimizes 
costs and maximizes efficiency. The second one is to create demand, which means not only meet the existing demand, but to generate and stimulate new demand by offering low fares and flights to destinations unexplored.

Ryanair, the largest low-cost airline in Europe, follows this second model, trying to identify potential untapped markets, focusing on regional or secondary airports. Following this strategy, it seeks to negotiate reduced rates and tax incentives from local authorities. This is usually effective, since the authorities are supposed to have interest in setting up the region, as this may induce economic growth and social location (Carrilho, 2009). Table 2 presents a comparison between the low-cost and traditional airlines in the early 2000 s.

Table 2 - Comparison between low-cost and traditional airlines model ${ }^{2}$

\begin{tabular}{|c|c|c|}
\hline & Low-cost carriers & Traditional network Airlines (early 2000s) \\
\hline & Simple product & Complex product \\
\hline \multirow{3}{*}{ Fares } & Low, simple - one-way & Round trip - complex \\
\hline & Minimum restriction & Multiple restriction \\
\hline & $\begin{array}{l}\text { Minimum restriction } \\
\text { Fares rise nearer departure }\end{array}$ & Lower fares last minute \\
\hline \multirow{3}{*}{ Distribution } & Avoid travel agents & Dependent on travel agents \\
\hline & Aim $100 \%$ direct: either online or call centre & Own ticket offices/call centre \\
\hline & Ticketless & Paper tickets \\
\hline \multirow{5}{*}{ In flight } & Single class & 2 or 3 classes \\
\hline & High-density seating & Low seat density \\
\hline & No seat assignment & Assigned seats \\
\hline & No meals or free drinks & In-flight catering \\
\hline & Simple operations & Complex operation \\
\hline \multirow{2}{*}{ Aircraft } & Single type - maximum two & Multiple types - aircraft tailored to route \\
\hline & High utilization (11 hours/day) & Low utilization on short sectors \\
\hline \multirow{3}{*}{ Sectors } & Short -500 to $1.000 \mathrm{~km}$ & From ultra-short to long \\
\hline & Point-to-point & Hub-based network \\
\hline & No hubbing or connecting flights & Pax-Emb/flights connect at hub \\
\hline Schedules & Used to shift demand & Response to current demand \\
\hline \multirow{2}{*}{ Airports } & Secondary or uncongested (where possible) & Focus on large airports \\
\hline & 20-30 minutes turn around & 1 hour turn-around on short sectors \\
\hline \multirow{3}{*}{ Staff } & Competitive wages & Higher wages \\
\hline & Profit-sharing & Minimal profit-sharing \\
\hline & High productivity & Over-staffed \\
\hline
\end{tabular}

${ }^{2}$ Source: Doganis (2010). 
Low cost carriers operating in Brazil present some differences from classical low cost model defined by Doganis (2010). Fleury (2010) noticed that there are some differences between classical low cost strategy and the Brazilian traditional low-cost. For instance, in Brazil the airlines use congested airports and big cities, as well as traditional airlines. This is due in large part by lack of infrastructure in the country, which does not offer many options for alternative airports. Other difference refers to rates that in Brazil are more complex than the traditional model. Actually Brazilian low cost airlines are closer to full services companies.

\section{Methodology}

The methodology adopted in this research is based on AHP (Analytic Hierarchy Process) and followed the next steps:

1. Determination of factors to be ranked in building companies' strategy and definition of the experts to answer the questionnaires;

2. Elaboration of questionnaires based on the factors;

3. Send the questionnaires to experts;

4. Elaboration of the second questionnaires combining the four most voted factors in the first round, in pairs;

5. Send this second questionnaire to the same experts;

6. Determination of the weights of each factor based on a second questionnaire;

7. Creation of a matrix using the factors applying principles of AHP decision support;

8. Determining the hierarchy of the final cost analysis.

Questionnaires were elaborated using Google Docs, which allows the creation of forms with multiple choice questions. Questionnaires were sent by e-mails to experts picked up from airlines, academic and regulatory agency. 
The application of AHP principles allowed to weight the experts responses and to establish a ranking of the costs factors to be considered when define airlines strategy.

\subsection{AHP (Analytic Hierarchy Process)}

To achieve the ranking of the most important factors in developing a strategy to reduce operating cost of an airline, we used a method based on the Analytic Hierarchy Process (AHP).

Considering the Theory of Discrete Multicriteria Decisions, AHP has been one of the first methods developed, having been created in the 80's by Thomas Saaty. It has applications in various fields of knowledge such as social, political, economic and technological. Its main attraction is to incorporate both quantitative and qualitative criteria in its analysis (Vieira, 2006).

One of the principles on which the AHP is based is on this prioritization. These are obtained by means of pairwise comparisons. The rationale for this type of comparison is the human capacity to perceive the relationship between situations and objects observed by comparing pairs with respect to a given criterion (Vieira, 2006).

In this work, we used the structure proposed by this method to perform the determination of the weights, without using, however, the fundamental scale of Saaty (Vieira, 2006), which assigns a priority value of one element over another.

\subsection{Definition of the factors to be ranked and definition of experts}

First of all, it was took into account the list cost determinants according to Doganis (2010) as showed in Table 1 . They were excluded the costs determined by external factors, because the companies have little control on them and the others were presented to experts: Cost of labor; Type/characteristics of the aircraft; Route structure/network characteristics; Airline marketing and product policy; Airline financial policy; Corporate strategy and Quality of management. Questionnaires also presented an space that could be used to additional comments. Experts should choose four cost determinants that are considered more important among the others. 
The questionnaire was sent to ten experts, representing the academia, the airlines and the regulatory agency. It was obtained five questionnaires properly answered from:

- $01 \mathrm{PhD}$ in Economics, Professor with more than 10 years of experience;

- 01 MSc in Air Transportation, Senior Flight Operations in an International Airline;

- 01 Technician from Brazilian Civil Aviation Agency;

- 01 Aeronautical Engineer, Vice President of Planning and Alliances from an International Airline;

- $01 \mathrm{PhD}$ in Transportation Engineering, Professor with more than 10 years of experience.

\subsection{Determination of the weights of each factor}

Based on the tabulation of the number of responses obtained by each of the factors presented to the experts, it was designed a second questionnaire, also sent to the same experts, in order to determine the weights of the four factors that had the greatest number of votes. In the second questionnaire, the combination was made of four factors, in pairs, resulting in six combinations. The experts then had to choose the factor was most relevant to a strategy of reducing operating costs for each combination.

To determine the priority of one factor over another, it was made the sum of responses from all experts. These preferences were organized in the form of a square matrix, called the decision matrix or dominant. The elements of this matrix represent the number of times in which one factor dominates or is dominated by the other. Each element aij of the row vector of the decision matrix shows the dominance of the factor $\mathrm{Ai}$ over the factor $\mathrm{Aj}$. The main diagonal is populated with a value to represent the non-dominance of one factor over another that the fundamental scale corresponds to the value 1. Figure 1 illustrates the decision matrix. 


$$
\begin{array}{ccc}
a_{11} & \cdots & a_{1 n} \\
\vdots & \ddots & \vdots \\
a_{n 1} & \cdots & a_{n n}
\end{array}
$$

Figure 1 - Decision Matrix

After building the decision matrix, its standardization was done by dividing each array element by the sum of the elements belonging to his column. The vector of priority factors was obtained through the arithmetic mean of the elements of the same row of the matrix has normalized (Nykiel, 2009).

Thus, the vector was obtained which shows the relevance of each factor analyzed for a strategy to reduce cost airlines.

\section{Results}

In this item it will be presented and analyzed the results of the two rounds of questionnaires as well as the final results of the research.

\subsection{Results of the first round of questions}

The first round of questions was used to determine the four most important factors in developing a strategy to reduce operating cost of an airline. To this end, the votes were counted for each of the five experts in a questionnaire. The result is shown in Table 3.

The type and characteristics of the aircraft used and route structure and the mesh were considered relevant by all the experts. It shows the importance of these items to determine the costs of an airline. In addition, there were factors that did not receive any votes, like marketing and product policy and financial policy, which can indicate that they are not very relevant from the experts consulted in building a strategy to reduce costs. 
Table 3 - Results of the first questionnaire

\begin{tabular}{|l|c|}
\hline \multicolumn{1}{|c|}{ Cost determinant } & Votes \\
\hline Cost of labor & 4 \\
\hline Type/characteristics of the aircraft & 5 \\
\hline Route structure/network characteristics & 5 \\
\hline Airline marketing and product policy & 0 \\
\hline Airline financial policy & 0 \\
\hline Corporate strategy & 2 \\
\hline Quality of management & 4 \\
\hline
\end{tabular}

\subsection{Results of the second round of questions}

From the four factors most votes in the first round of questions was then prepared the second questionnaire with the combination in pairs. Experts selected which most relevant factor in each combination. Table 4 shows the results questionnaire sent to experts.

Table 4 - Results from second round questionnaires, in pairs

\begin{tabular}{|l|c|c|}
\hline Question & Factor & Votes \\
\hline \multirow{2}{*}{ Question 1 } & Cost of labor & 1 \\
\cline { 2 - 3 } & Type/characteristics of the aircraft & 4 \\
\hline \multirow{2}{*}{ Question 2 } & Cost of labor & 2 \\
\cline { 2 - 3 } & Qute structure/network characteristics & 3 \\
\hline \multirow{2}{*}{ Question 3 } & Cuality of management & 3 \\
\cline { 2 - 3 } & Type/characteristics of the aircraft & 2 \\
\hline \multirow{2}{*}{ Question 4 } & Quality of management & 1 \\
\cline { 2 - 3 } & Type/characteristics of the aircraft & 1 \\
\hline \multirow{2}{*}{ Question 5 } & Route structure/network characteristics & 4 \\
\cline { 2 - 3 } & Quality of management & 2 \\
\hline \multirow{2}{*}{ Question 6 } & Route structure/network characteristics & 3 \\
\cline { 2 - 3 } & &
\end{tabular}




\subsection{Construction of the Decision Matrix}

Based on the result obtained in the second questionnaire, it was possible to construct the decision matrix that shows the relevance of a factor with respect to another. Each of the four factors was named as follows:
A - Cost of labor;
B - Type and characteristics of the aircraft used;
C - Structure of the routes and the mesh;
D - Quality management.

Thus, the decision matrix in which is shown relative importance of each of the factors on the other hand, was as shown in Table 5, A B C D:

Table 5 - Matrix judgment obtained

\begin{tabular}{|c|c|c|c|c|}
\cline { 2 - 5 } \multicolumn{1}{c|}{} & $\mathrm{A}$ & $\mathrm{B}$ & $\mathrm{C}$ & $\mathrm{D}$ \\
\hline $\mathrm{A}$ & 1 & $1 / 4$ & $2 / 3$ & $3 / 2$ \\
\hline $\mathrm{B}$ & 4 & 1 & $1 / 4$ & 4 \\
\hline $\mathrm{C}$ & $3 / 2$ & 4 & 1 & $3 / 2$ \\
\hline $\mathrm{D}$ & $2 / 3$ & $1 / 4$ & $2 / 3$ & 1 \\
\hline
\end{tabular}

Normalization was done by dividing each matrix element by the sum of the elements belonging to his column. The normalized matrix is shown in Table 6 .

Table 6 - Matrix of standardized decision

\begin{tabular}{|c|c|c|c|c|}
\cline { 2 - 5 } \multicolumn{1}{c|}{} & $\mathrm{A}$ & $\mathrm{B}$ & $\mathrm{C}$ & $\mathrm{D}$ \\
\hline $\mathrm{A}$ & 0,14 & 0,05 & 0,26 & 0,19 \\
\hline $\mathrm{B}$ & 0,56 & 0,18 & 0,10 & 0,50 \\
\hline $\mathrm{C}$ & 0,21 & 0,73 & 0,39 & 0,19 \\
\hline $\mathrm{D}$ & 0,09 & 0,05 & 0,26 & 0,13 \\
\hline
\end{tabular}




\subsection{Hierarchy of the final factors}

To determine the vector of priority factors, it was done the arithmetic mean of the elements of each row of the matrix as standard. The result is shown in Table 7.

\section{Table 7 - Priority of factors}

\begin{tabular}{|c|c|}
\hline Factor & Weight \\
\hline $\mathrm{A}$ & 0,16 \\
\hline $\mathrm{B}$ & 0,33 \\
\hline $\mathrm{C}$ & 0,38 \\
\hline $\mathrm{D}$ & 0,13 \\
\hline
\end{tabular}

This vector represents the end of the ranking factors. The factor of greatest value in the priority vector is one that has greater relevance in the same way that the lower value is the least among those analyzed. Thus, the final ranking of the factors analyzed was as follows:

1) Structure of the routes and the mesh;

2) Type and characteristics of the aircraft used;

3) Cost of labor; and

4) Quality Management.

This indicates that the first two factors are both very important strategy for reducing the cost of an airline, while the latter two have a much lower degree of importance. Thus, managers should focus their attention and resources in route structure and the mesh and the type and characteristics of the aircraft used to obtain more meaningful results. In the following topics will be analyzed each of the four factors. 


\section{Conclusion}

The main objective of this research was to propose a ranking of the main factors in strategies to reduce cost of airlines. The factors presented here are considered under corporate control. It was applied a structure based on the method of decision support AHP (Analytic Hierarchy Process) and questionnaires answered by experts from the industry.

Air transportation is a market-based industry after deregulation and the hierarchy of the cost factors can be useful for managers of airlines when defining priority actions to reduce their costs and achieving competitive advantage over competitors. It should be noted that, considering that air transportation is a dynamic market, the results showed in this paper should be considered from the current situation. It is recommended its update over time to include other factors and also to evaluate the weight of them.

\section{References}

Barla, P. and Koo, B. (1999) Bankruptcy protection and pricing strategies in the US airline industry. Transportation Research Part E, vol. 35, pp. 101-120.

Borenstein, S. and Rose, N. L. (2007) How airline markets work... or do they? Regulatory reform in the airline industry. National Bureau of Economic Research. Working Paper, n. 13452. Available at www.nber.org/papers/w13452.

Brasil (2011) Agência Nacional de Aviação Civil - ANAC. Anuários Estatísticos. Available at www.anac.gov.br. Accessed Sept 29.

Brasil (2011) Ministry of Finance. Produto Interno Bruto. Available at www.fazenda.gov.br. Accessed Sep 26, 2011.

Carrilho, P. A. S. (2009) Competitive Strategies for Attracting Low Cost Airlines. Master's thesis. Instituto Superior Técnico - Technical University of Lisbon, October.

Coelho, L. C. (2010) Strategies and Competitive Advantages. Portal INBRASC, Available at www.inbrasc.org.br/pesquisa/pesquisas_realizadas. Accessed 30 March, 2011.

Doganis, R. (2010) Flying Off Course: Airline Economics and Marketing. Fourth Edition. Routledge, London.

Fleury, P. L. (2010) Estudo sobre estratégias de negócio de empresas de transporte aéreo para atender o mercado de baixa renda: estudo de caso. Tese de Mestrado. Universidade de São Paulo, São Paulo. 
Nykiel, T. (2009) Análise do Impacto do Ruído Aeronáutico em 36 Aeroportos Brasileiros. Trabalho de Conclusão de Curso (Graduação) - Instituto Tecnológico de Aeronáutica, São José dos Campos.

Porter, M. E. (1989) Vantagem Competitiva: criando e sustentando um desempenho superior. Rio de Janeiro: Campus.

Vieira, G. H. (2006) Análise e Comparação dos Métodos de Decisão Multicritério AHP Clássico e Multiplicativo. Trabalho de Conclusão de Curso (Graduação) - Instituto Tecnológico de Aeronáutica, São José dos Campos.

Wei, W. and Hansen, M. (2003) Cost Economics of Aircraft Size. Journal of Transport Economics and Policy, vol. 37, n. 2, pp. 279-296. 